\title{
Hypocretin-1 causes G protein activation and increases ACh release in rat pons
}

\author{
René Bernard, ${ }^{1}$ Ralph Lydic ${ }^{2}$ and Helen A. Baghdoyan ${ }^{1,2}$ \\ Departments of ${ }^{1}$ Pharmacology and \\ ${ }^{2}$ Anaesthesiology, University of Michigan, 7433 Medical Sciences Building I, 1150 West Medical Center Drive, Ann Arbor, MI 48109, \\ USA
}

Keywords: $\left[{ }^{35}\right.$ S]GTPyS autoradiography, dorsal raphe nucleus, locus coeruleus, orexin, REM sleep

\begin{abstract}
The effects of the arousal-promoting peptide hypocretin on brain stem G protein activation and ACh release were examined using 16 adult Sprague-Dawley rats. In vitro $\left[{ }^{35} \mathrm{~S}\right] \mathrm{GTP} \gamma \mathrm{S}$ autoradiography was used to test the hypothesis that hypocretin-1-stimulated G protein activation is concentration-dependent and blocked by the hypocretin receptor antagonist SB-334867. Activated G proteins were quantified in dorsal raphe nucleus (DR), locus coeruleus (LC) and pontine reticular nucleus oral part (PnO) and caudal part (PnC). Concentration-response data revealed a significant $(P<0.001)$ effect of hypocretin-1 $(2-2000 \mathrm{nM})$ in all brain regions examined. Maximal increases over control levels of $\left[{ }^{35}\right.$ S]GTP $\gamma$ S binding were $37 \%$ (DR), 58\% (LC), 52\% (PnO) and 44\% (PnC). SB-334867 (2 $\left.\mu \mathrm{M}\right)$ significantly $(P<0.002)$ blocked hypocretin-1 $(200 \mathrm{nM})$-stimulated $\left[{ }^{35} \mathrm{~S}\right] \mathrm{GTP} \gamma \mathrm{S}$ binding in all four nuclei. This is the first autoradiographic demonstration that hypocretin-1 activates G proteins in arousal-related brain stem nuclei as a result of specific receptor interactions. This finding suggests that some hypocretin receptors in brain stem couple to inhibitory $\mathrm{G}$ proteins. In vivo microdialysis was used to test the hypothesis that $\mathrm{PnO}$ administration of hypocretin-1 increases ACh release in PnO. Dialysis delivery of hypocretin-1 $(100 \mu \mathrm{M})$ significantly $(P<0.002)$ increased $(87 \%)$ ACh release. This finding is consistent with the interpretation that one mechanism by which hypocretin promotes arousal is by enhancing cholinergic neurotransmission in the pontine reticular formation.
\end{abstract}

\section{Introduction}

The hypothalamic neuropeptides hypocretin (hcrt)-1 and hcrt-2 (de Lecea et al., 1998), also named orexin-A and orexin-B (Sakurai et al., 1998), are thought to participate in the regulation of behavioural arousal (Kilduff \& Peyron, 2000). In animals, intracranial administration of hcrt increases wakefulness (Hagan et al., 1999; Bourgin et al., 2000; Piper et al., 2000; España et al., 2001; Xi et al., 2001), and experimentally induced losses of hcrt neurons disrupt wakefulness (Gerashchenko et al., 2001; Hara et al., 2001). Animal models of the human sleep disorder narcolepsy are characterized by defective hort receptors (Lin et al., 1999) or a lack of the peptide (Chemelli et al., 1999), and human narcoleptic patients show low or undetectable hcrt levels in cerebrospinal fluid (Nishino et al., 2000, 2001) and a loss of hcrt neurons (Peyron et al., 2000; Thannickal et al., 2000). The clinical phenotype of narcolepsy includes excessive daytime sleepiness, disrupted nighttime sleep and the onset of rapid eye movement (REM) sleep periods or traits directly from wakefulness (Nishino \& Mignot, 1997). Narcolepsy can be viewed as a disorder of the normal boundaries between different arousal states, and it has been suggested that the loss of hypocretin in narcolepsy may facilitate inappropriate transitions between wakefulness and sleep (Scammell, 2003).

The mechanisms by which hert regulates states of arousal are not well understood. Hcrt-synthesizing neurons project to arousal-promoting brain stem nuclei including the dorsal raphe nucleus (DR), locus coeruleus (LC) and pontine reticular nucleus, oral part (PnO) and caudal

Correspondence: Helen A. Baghdoyan, as above.

E-mail: helenb@umich.edu

part (PnC) (Peyron et al., 1998). Hcrt excites noradrenergic LC (Hagan et al., 1999; Horvath et al., 1999) and serotonergic DR (Brown et al., 2001) neurons, and may promote wakefulness by elevating monoaminergic tone (Kilduff \& Peyron, 2000). Hcrt-1 microinjection into cat pontine reticular formation triggers REM sleep (Xi et al., 2002), suggesting that hert-1 may also promote brain activation by enhancing pontine cholinergic neurotransmission (Kilduff \& Peyron, 2000).

Hcrt binds two guanine nucleotide binding protein ( $\mathrm{G}$ protein)coupled receptors, hcrt-r1 and hcrt-r2 (Sakurai et al., 1998). Hcrt-r1 shows a higher affinity for hcrt-1 than for hort-2, whereas hcrt-r2 shows equally high affinity for both peptides (Sakurai et al., 1998). In vitro $\left[{ }^{35} \mathrm{~S}\right]$ guanylyl-5'-O- $(\gamma$-thio $)$ triphosphate $\left(\left[{ }^{35} \mathrm{~S}\right] \mathrm{GTP} \gamma \mathrm{S}\right)$ autoradiography offers a unique approach for identifying brain regions where agonists bind to receptors to cause G protein activation (Sim et al., 1995; Sóvágó et al., 2001). Hcrt-1 has been shown to activate Gproteins in arousal-related brain stem nuclei (Bernard et al., 2002a). The present study used in vitro $\left[{ }^{35} \mathrm{~S}\right] \mathrm{GTP} \gamma \mathrm{S}$ autoradiography to test the hypothesis that hert-1-stimulated $G$ protein activation in DR, $\mathrm{LC}, \mathrm{PnO}$ and $\mathrm{PnC}$ is concentration-dependent, saturates, and can be blocked by the hort receptor antagonist SB-334867 (Smart et al., 2001). The hypothesis was confirmed, indicating that hort-induced $\left[{ }^{35} \mathrm{~S}\right] \mathrm{GTP} \gamma \mathrm{S}$ binding is receptor-mediated. An in vivo consequence of hcrt-1-stimulated $\mathrm{G}$ protein activation was investigated by testing the additional hypothesis that microdialysis delivery of hert-1 to rat PnO increases ACh release in PnO. The second hypothesis was supported, consistent with the interpretation that one mechanism by which hort produces arousal may be by enhancing pontine cholinergic neurotransmission. Portions of these data have been presented as abstracts (Bernard et al., 2002b; Bernard et al., 2003a). 


\section{Materials and methods}

\section{Chemicals and animals}

Hcrt-1 was purchased from California Peptide Research (Napa, CA, USA). SB-334867 was provided by GlaxoSmithKline (Essex, UK). Reflection autoradiography film (Kodak X-OMAT Blue XB-1) and $\left[{ }^{35} \mathrm{~S}\right] \mathrm{GTP} \gamma \mathrm{S}$ were obtained from PerkinElmer Life Science Products (Boston, MA, USA). Carbachol, guanosine 5'-diphosphate (GDP), guanosine $5^{\prime}$-O- $(\gamma$-thio)triphosphate $(\mathrm{GTP} \gamma \mathrm{S})$, and chemicals used for buffers, Ringer's solution, standard curves and mobile phase were purchased from Sigma-Aldrich (St Louis, MO, USA). Adult male Sprague-Dawley rats (250-350 g) were purchased from Charles River Laboratories (Wilmington, MA, USA) and housed in a 12-h light-dark cycle for at least 1 week prior to use. All experiments were performed in accordance with the Guide for the Care and Use of Laboratory Animals (National Academy Press, Washington, DC, 1996) and with approval by the University of Michigan Committee on Use and Care of Animals.

\section{Preparing tissue sections and performing in vitro $\left.{ }^{35} S\right] G T P \gamma S$ autoradiography}

Rats were always decapitated at the same time of day (4-5 h after light onset). Brains were removed and immediately frozen in a bilayer composed of 2-methylbutane and 1-bromobutane at $-30{ }^{\circ} \mathrm{C}$. Coronal brain stem sections $(20 \mu \mathrm{m}$ thick) were cut serially using Hacker Bright (Fairfield, NJ, USA) or Leica CM3050 S (Leica Microsystems, Nussloch, Germany) cryostats. Adjacent pairs of sections from approximately bregma -10.30 to $-7.04 \mathrm{~mm}$ (Paxinos \& Watson, 1998) were thaw-mounted onto gelatin-coated glass slides, dried in a vacuum desiccator $\left(4^{\circ} \mathrm{C}\right)$ and stored at $-70^{\circ} \mathrm{C}$ before being used in an assay.

$\left[{ }^{35} \mathrm{~S}\right] \mathrm{GTP} \gamma \mathrm{S}$ binding assays were performed as previously described (Sim et al., 1995; Capece et al., 1998; Bernard et al., 2002a). Assay buffer contained $50 \mathrm{mM}$ Tris- $\mathrm{HCl}, 3 \mathrm{mM} \mathrm{MgCl}, 0.2 \mathrm{mM}$ EGTA and $100 \mathrm{~mm} \mathrm{NaCl}$ (pH 7.4). Slide-mounted tissue sections were brought to room temperature and incubated for $2 \mathrm{~h}$ in $0.04 \mathrm{nM}\left[{ }^{35} \mathrm{~S}\right] \mathrm{GTP} \gamma \mathrm{S}$ and $2 \mathrm{mM}$ GDP. Different drug treatments during the 2-h incubation were applied for the concentration-response assays and for the antagonist blocking assays, as described below. For all assays, the incubation period was terminated by rinsing tissue sections in ice-cold $50 \mathrm{mM}$ Tris-HCl buffer ( $\mathrm{pH}$ 7.0) followed by ice-cold deionized water.

For the concentration-response assays, tissue sections were assigned serially to one of seven assay conditions. The first assay condition determined basal $\left[{ }^{35} \mathrm{~S}\right] \mathrm{GTP} \gamma \mathrm{S}$ binding in the absence of an exogenous agonist. Conditions two to five contained hcrt-1 (2, 20, 200 or $2000 \mathrm{nM}$, respectively) to test the hypothesis that hcrt-1-stimulated G protein activation is concentration-dependent. Condition six used the cholinergic agonist carbachol $(1 \mathrm{mM})$ as a positive assay control (Capece et al., 1998). Assay condition seven determined nonspecific binding using excess unlabelled GTP $\gamma \mathrm{S}(10 \mu \mathrm{M})$.

For the study designed to test the hypothesis that hort-1-stimulated Gprotein activation can be blocked by the specific hcrt receptor antagonist SB-334867, tissue sections were assigned serially to one of five assay conditions: basal, nonspecific binding, hert-1 (200 nM), SB-334867 $(2 \mu \mathrm{M})$, and hcrt-1 (200 nM) + SB-334867 (2 $\mu \mathrm{M})$. SB334867 is poorly soluble in water, requiring the use of dimethyl sulfoxide (DMSO) (Duxon et al., 2001). To control for nonspecific effects of DMSO on $\left[{ }^{35} \mathrm{~S}\right] \mathrm{GTP} \gamma \mathrm{S}$ binding, the buffer used for all five assay conditions contained $0.02 \%$ DMSO.

Post-assay processing of the tissue sections included drying, exposing to autoradiography film, and staining. Tissue sections were initially dried in a room-temperature stream of air. The drying process was completed by keeping the sections in a vacuum desiccator overnight.
The sections were then put into autoradiography cassettes (Fisher Scientific, Pittsburg, PA, USA) together with ${ }^{14} \mathrm{C}$ microscale standards (31-883 nCi/g, Amersham Biosciences, Arlington Heights, IL, USA) and X-OMAT Blue XB-1 film (Eastman Kodak Company, Rochester, NY, USA). After $72 \mathrm{~h}$ of exposure at room temperature, films were developed with a Kodak X-OMAT Model 2002A film processor. Tissue sections were fixed with paraformaldehyde vapors $\left(80^{\circ} \mathrm{C}\right)$ and stained with Cresyl Violet.

\section{Quantifying $\left[{ }^{35} S\right] G T P \gamma S$ binding}

A Cohu CCD camera with a Micro Nikon $60 \mathrm{~mm}$ objective, the Scion Image $1.62 \mathrm{c}$ version of NIH Image, and a G3 Apple Macintosh computer were used to produce digital images from each autoradiogram and Cresyl Violet-stained tissue section. The following procedure was used to quantify $\left[{ }^{35} \mathrm{~S}\right] \mathrm{GTP} \gamma \mathrm{S}$ binding in DR, LC, PnO, and PnC. Each nucleus was localized and digitally outlined on the Cresyl Violet image according to a rat brain atlas (Paxinos \& Watson, 1998). Outlines were transferred to the identical position on the digitized version of the autoradiogram and optical density was quantified. To calculate total $\left[{ }^{35} \mathrm{~S}\right] \mathrm{GTP} \gamma \mathrm{S}$ binding, optical density was converted to $\mathrm{nCi} / \mathrm{g}$ brain tissue using a ${ }^{14} \mathrm{C}$ correction factor (Capece et al., 1998). Mean nonspecific binding values for each of the four nuclei were subtracted from individual total $\left[{ }^{35} \mathrm{~S}\right] \mathrm{GTP} \gamma \mathrm{S}$ binding values to produce specific binding values for each nucleus. The number of individual optical density measurements obtained from each nucleus is dependent on the rostralto-caudal extent of that nucleus and whether the nucleus is a midline (DR) or a bilateral (LC, PnO, PnC) structure. An average specific binding value was calculated for each nucleus from every animal.

Data were analysed using one-way analysis of variance (ANOVA) and Tukey-Kramer multiple comparisons test. The alpha level was set at $P<0.05$. GraphPad Prism software (version 3.0a for Macintosh, GraphPad Software, San Diego, CA, USA) was used for nonlinear regression analysis of hcrt-1 concentration-response binding data. Sigmoid curves were fitted using the following equation:

$$
\begin{aligned}
\text { specific }\left[{ }^{35} \mathrm{~S}\right] \text { GTP } \gamma \mathrm{S} \text { binding } & =\text { basal binding }+(\text { maximal binding } \\
& - \text { basal binding }) /\left(1+10 \hat{(}\left(\log \mathrm{EC}_{50}-X\right)\right)
\end{aligned}
$$

where $X$ represents the logarithm of the hcrt-1 concentration. These analyses were used to determine the concentration of hort- 1 which produced $50 \%$ of the maximal increase in $\left[{ }^{35} \mathrm{~S}\right] \mathrm{GTP} \gamma \mathrm{S}$ binding $\left(\mathrm{EC}_{50}\right)$ and the coefficient of determination $\left(r^{2}\right)$ for each nucleus.

\section{Measuring the effects of hort-1 on pontine ACh release}

Every microdialysis experiment was performed according to the following series of procedures. After quantifying the percentage of ACh recovered in vitro by a dialysis probe, a rat was anaesthetized and the probe was aimed stereotaxically for either the left or right $\mathrm{PnO}$; details are given below. In vivo dialysis samples were collected and immediately analysed for ACh content. The dialysis probe was removed from the brain and probe recovery of ACh again was determined in vitro. Each rat was used for only one experiment. Placement of the dialysis probe in the $\mathrm{PnO}$ was confirmed histologically. These steps are described in detail below.

\section{Using in vivo microdialysis to deliver hert-1 to the pons and collect ACh from the pons}

CMA/11 microdialysis probes (1 mm length, $0.24 \mathrm{~mm}$ membrane diameter, $6 \mathrm{kDa}$ cut-off; CMA Microdialysis, North Chelmsford, MA, USA) were connected to a CMA/100 pump which provided a constant $2.0 \mu \mathrm{L} / \mathrm{min}$ flow rate. Probes were perfused continuously with either Ringer's solution ( $147 \mathrm{mM} \mathrm{NaCl}, 4.0 \mathrm{mM} \mathrm{KCl}, 2.4 \mathrm{mM} \mathrm{CaCl}_{2}$, 
$10 \mu \mathrm{M}$ neostigmine bromide, pH5.8-6.2) or with hert-1 (100 $\mu \mathrm{M})$ dissolved in Ringer's solution and adjusted to $\mathrm{pH}$ 5.8-6.2 with $\mathrm{NaOH}$. Dialysis samples $(30 \mu \mathrm{L})$ were collected every $15 \mathrm{~min}$. Before positioning the dialysis probe in the brain, the probe was placed in a solution of known ACh concentration and five 30- $\mu \mathrm{L}$ samples were collected and analysed for ACh. These data were used to calculate percentage of ACh recovered by the probe.

Rats were deeply anaesthetized with $3-4 \%$ isoflurane (Abbott Laboratories, North Chicago, IL, USA) in $100 \% \mathrm{O}_{2}$ and placed in a Model 962 ultra-precise small-animal stereotaxic instrument (David Kopf Instruments, Tujunga, CA, USA) equipped with a Model 920 rat adaptor, anaesthesia mask and ear bars. A warm water blanket $\left(37^{\circ} \mathrm{C}\right)$ connected to a re-circulating heat pump system (Gaymar Industries, Orchard Park, NY, USA) was used to maintain body temperature during anaesthesia. Delivered isoflurane concentration and core body temperature were measured using a Cardiocap ${ }^{\mathrm{TM}} / 5$ monitor (DatexOhmeda, Madison, WI, USA). Respiratory rate (breaths/min) was counted manually every $15 \mathrm{~min}$. The scalp was opened and an access hole for the dialysis probe was made through the skull using a Dremel (Racine, WI, USA). A dialysis probe was aimed for the PnO according to the following stereotaxic coordinates: $8.6 \mathrm{~mm}$ posterior to bregma, $1.2 \mathrm{~mm}$ lateral from the midline and $9.2 \mathrm{~mm}$ ventral to bregma (Paxinos \& Watson, 1998).

After the dialysis probe was in the brain, delivered isoflurane concentration was set at $1.5 \%$ and held constant during sample collection. Dialysis samples were collected for at least $45 \mathrm{~min}$ to ensure stable ACh levels. Five control samples $(75 \mathrm{~min})$ then were collected during dialysis with Ringer's solution before hcrt-1 delivery was initiated by turning a CMA/110 liquid switch. Five dialysis samples $(75 \mathrm{~min})$ were collected during hort-1 delivery. When the dialysis probe was removed from the brain, the scalp wound was closed using sutures. Animals were allowed to recover from anaesthesia and survive 3-4 days to permit formation of a glial scar at the site where the dialysis probe had been placed.

Immediately following removal of the dialysis probe from the brain, the probe was placed in a solution of known ACh concentration and five dialysis samples were collected and analysed for ACh. Comparison between pre- and postexperimental probe recoveries by twosample Student's $t$-test $(P<0.05)$ ensured that changes in ACh release measured during each experiment resulted from drug administration and not from intraexperimental changes in the dialysis membrane (Vazquez \& Baghdoyan, 2003). The present study includes only experiments where pre- and postexperimental probe recoveries did not change significantly in the hypothesized direction of the drug effect.

\section{Quantifying ACh}

Dialysis samples were analysed by high performance liquid chromatography with electrochemical detection (Bioanalytical Systems (BAS), West Lafayette, IN, USA, as previously described (Baghdoyan et al., 1998; Vazquez \& Baghdoyan, 2003). ACh was converted proportionally into $\mathrm{H}_{2} \mathrm{O}_{2}$ by an immobilized enzyme reactor column and $\mathrm{H}_{2} \mathrm{O}_{2}$ was detected amperometrically by a platinum electrode $(+0.5 \mathrm{~V})$ in reference to a $\mathrm{Ag}^{+} / \mathrm{AgCl}$ electrode. The subsequent chromatographic signal was digitized and quantified using ChromGraph ${ }^{\circledR}$ software (BAS) and a five-point standard curve (0.1-1.0 pmol ACh) created before each experiment. Differences in ACh before and during hcrt-1 administration were evaluated using paired $t$-test. The alpha level for statistical significance was $P<0.05$.

\section{Histologically identifying dialysis probe sites}

Rats were killed with an overdose of anaesthetic, and brains were removed for verification of probe placement. Brains were frozen immediately after removal and cut serially as $40-\mu \mathrm{m}$ coronal sections using a Leica cryostat. Sections then were fixed using paraformaldehyde vapors $\left(80^{\circ} \mathrm{C}\right)$, stained with Cresyl Violet, and visually inspected for evidence of a dialysis probe-induced lesion. Every section containing a lesion was digitized using a Cohu CCD camera with a Micro Nikon 60-mm objective. Digitized sections were compared with coronal plates from a rat brain atlas (Paxinos \& Watson, 1998) to determine the stereotaxic coordinates for each dialysis site.

\section{Results \\ Hcrt-1-induced G protein activation was concentration- dependent and blocked by the hcrt receptor antagonist SB-334867}

Figure 1 illustrates G protein activation by hert-1 in the pontine brain stem. Colour-coded autoradiograms show total $\left[{ }^{35} \mathrm{~S}\right] \mathrm{GTP} \gamma \mathrm{S}$ binding under basal conditions and after in vitro treatment with hert-1 $(2000 \mathrm{nM})$. Increased $\left[{ }^{35} \mathrm{~S}\right] \mathrm{GTP} \gamma \mathrm{S}$ binding over basal levels is indicated by more green, yellow and red colours. The boundaries of pontine brain stem nuclei where $\left[{ }^{35} \mathrm{~S}\right] \mathrm{GTP} \gamma \mathrm{S}$ binding was quantified and found to be significantly increased by hort-1 are outlined. These four nuclei include LC, PnC, DR and PnO. Visual inspection reveals that hcrt-1 also increased $\left[{ }^{35} \mathrm{~S}\right] \mathrm{GTP} \gamma \mathrm{S}$ binding in the posterodorsal tegmental nucleus (PDTg), ventrolateral periaqueductal grey (VLPAG) and median raphe nucleus (MnR). No $\left[{ }^{35} \mathrm{~S}\right] \mathrm{GTP} \gamma \mathrm{S}$ binding was observed in the facial nerve $(7 \mathrm{n})$.

Figure 2 summarizes basal and hcrt-1-stimulated specific $\left[{ }^{35} \mathrm{~S}\right] \mathrm{GTP} \gamma \mathrm{S}$ binding quantified for DR, LC, PnC and PnO. Results are based on 744 individual measurements obtained from four brains for DR, LC and PnC, and three brains for PnO. ANOVA revealed a significant concentration main effect of hert-1 on $G$ protein activation in DR (Fig. $2 \mathrm{~A} ; F_{4,19}=27.6, P<0.0001$ ), LC (Fig. $2 \mathrm{~B} ; F_{4,19}=11.4$, $P=0.0005$ ), PnC (Fig. 2C; $F_{4,19}=21.5, P<0.0001$ ) and $\mathrm{PnO}$ (Fig. $2 \mathrm{D} ; F_{4,14}=33.4, P<0.0001$ ). For all four nuclei, Tukey-Kramer multiple comparisons tests showed that $\left[{ }^{35} \mathrm{~S}\right] \mathrm{GTP} \gamma \mathrm{S}$ binding induced by 20,200 and $2000 \mathrm{nM}$ hcrt- 1 was significantly increased over basal levels. Hcrt-1 maximally increased $\left[{ }^{35} \mathrm{~S}\right] \mathrm{GTP} \gamma \mathrm{S}$ binding over basal values by $37 \%$ in DR (Fig. 2A), 58\% in LC (Fig. 2B), $44 \%$ in PnC (Fig. 2C) and 52\% in PnO (Fig. 2D).

Figure 3 provides quantitative data illustrating pharmacological antagonism of hert-1-stimulated $\left[{ }^{35} \mathrm{~S}\right] \mathrm{GTP} \gamma \mathrm{S}$ binding by SB334867. Results consist of 1496 measurements taken from six brains for DR, PnC and PnO, and five brains for LC. Repeated-measures ANOVA and post hoc Tukey-Kramer multiple comparisons tests showed that treatment with SB-334867 significantly decreased specific $\left[{ }^{35} \mathrm{~S}\right] \mathrm{GTP} \gamma \mathrm{S}$ binding induced by $200 \mathrm{nM}$ hert-1 in DR (Fig. 3A; $F_{3,23}=20.0, P<0.0001$ ), LC (Fig. 3B; $F_{3,19}=8.9, P=0.002$ ), PnC (Fig. $3 C ; F_{3,23}=22.6, P<0.0001$ ) and PnO (Fig. 3D; $F_{3,23}=24.7$, $P<0.0001)$. SB-334867 did not alter $\left[{ }^{35} \mathrm{~S}\right] \mathrm{GTP} \gamma \mathrm{S}$ binding in any nucleus studied.

\section{Microdialysis delivery of hcrt-1 increased ACh release in the pontine reticular formation}

The demonstration that in vitro treatment with hert-1 caused a concentration-dependent activation of $\mathrm{G}$ proteins in arousal-related nuclei encourages investigations into the functional consequences of in vivo hcrt-1 administration. Therefore, this study used dialysis to deliver hcrt-1 to the $\mathrm{PnO}$ while measuring ACh release in the PnO. Figure 4 summarizes histological data confirming that all dialysis sites were restricted to the PnO. The effect of hcrt-1 $(100 \mu \mathrm{M})$ on ACh release is shown in Fig. 5. Chromatographic peaks representing $\mathrm{ACh}$ in one 


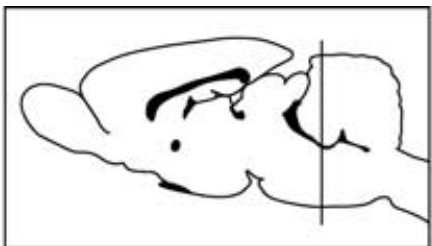

Bregma $-10.04 \mathrm{~mm}$
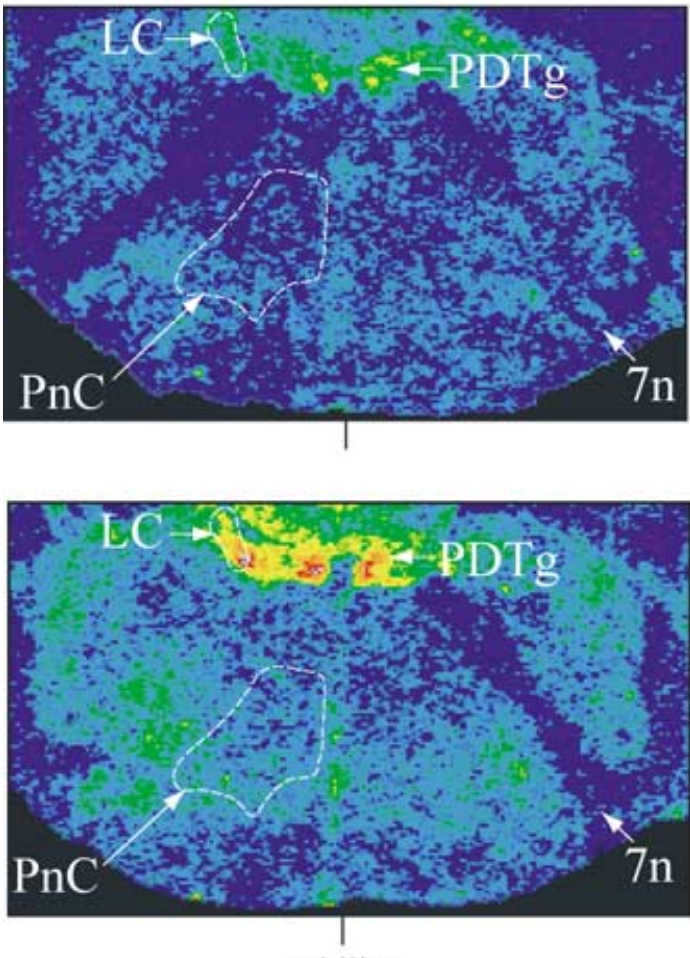

midline

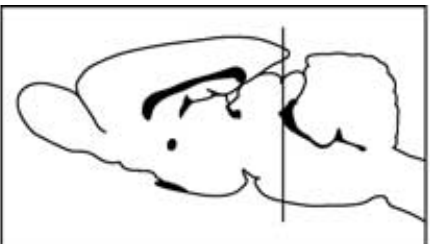

Bregma $-7.80 \mathrm{~mm}$
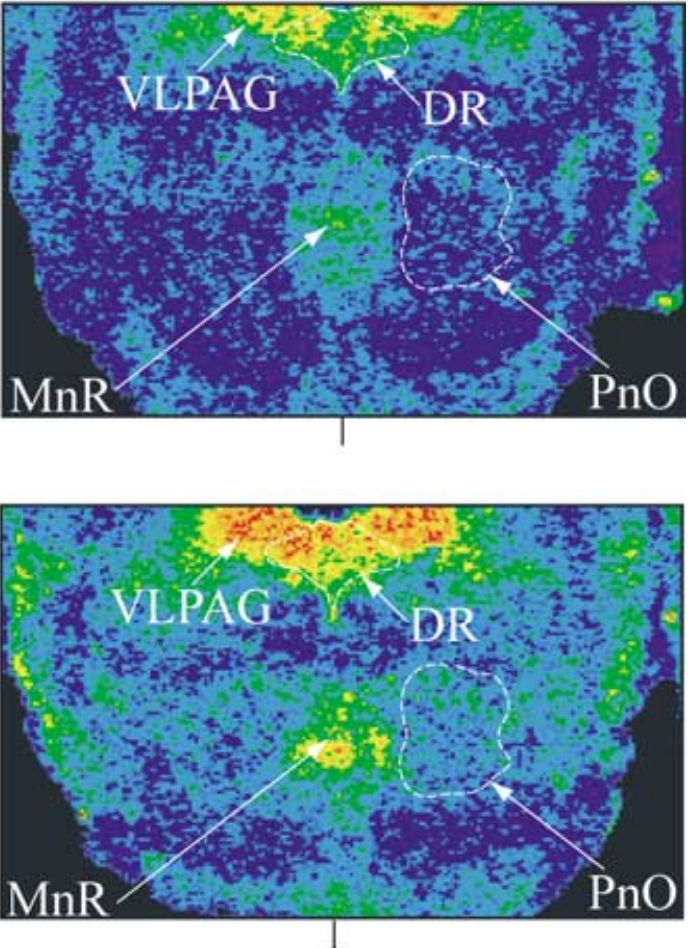

midline

\section{Hypocretin-1}

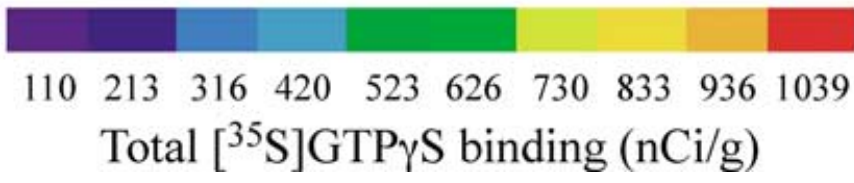

FIG. 1. Hcrt-1 activated G proteins in the pontine brain stem. Boxes at the top of each column show a sagittal schematic of the rat brain (from Paxinos \& Watson, 1998). The vertical line in each schematic indicates the anterior-posterior level (relative to bregma) of the coronal autoradiograms shown below. The colour-coded autoradiograms illustrate total $\left[{ }^{35} \mathrm{~S}\right] \mathrm{GTP} \gamma \mathrm{S}$ binding under basal conditions and following hert-1 (2000 nM) treatment.

sample obtained during dialysis with Ringer's (control) and one sample collected during dialysis delivery of hort-1 are presented in Fig. 5A. Figure 5B illustrates the time course of ACh release during one typical experiment. Each bar represents sequential ACh samples collected for $15 \mathrm{~min}$. By the second sampling interval during dialysis delivery of hcrt-1, ACh release was clearly increased over control levels. Figure 5C summarizes data from six microdialysis experiments. Hcrt-1 significantly increased ACh release by an average of $87 \%$ $\left(t_{5}=5.6, P<0.002\right)$. Hcrt-1 had no significant effect on respiratory rate or core body temperature.

\section{Discussion}

The data reported here show that hcrt-1-induced $\left[{ }^{35} \mathrm{~S}\right] \mathrm{GTP} \gamma \mathrm{S}$ binding in DR, LC and pontine reticular formation is concentration-dependent and blocked by a selective hert receptor antagonist. This is the first demonstration that, in brain stem nuclei known to regulate states of arousal, hcrt-1 activates G proteins as a consequence of specific receptor interactions. These results indicate that some hcrt receptors in the brain stem may couple to inhibitory (Gi-like) $\mathrm{G}$ proteins. This study also showed that in vivo administration of hcrt-1 to the pontine reticular formation increased $\mathrm{ACh}$ release in the pontine reticular formation. This finding suggests that hert may promote arousal by, in part, enhancing pontine cholinergic neurotransmission. The following discussion considers some of the strengths and limitations of the data, implications of the findings for G protein coupling of hort receptors, and inferences for arousal state control.

\section{Hcrt-1-stimulated G protein activation is receptor-mediated}

One advantage of in vitro $\left[{ }^{35} \mathrm{~S}\right] \mathrm{GTP} \gamma \mathrm{S}$ autoradiography is that brain anatomy is preserved. Consequently, agonist-stimulated G protein activation can be quantified in specific histologically defined brain regions (Fig. 1). The present data show that for DR, LC, PnO and PnC, hort- 1 caused a significant increase in $\left[{ }^{35} \mathrm{~S}\right] \mathrm{GTP} \gamma \mathrm{S}$ binding which was 

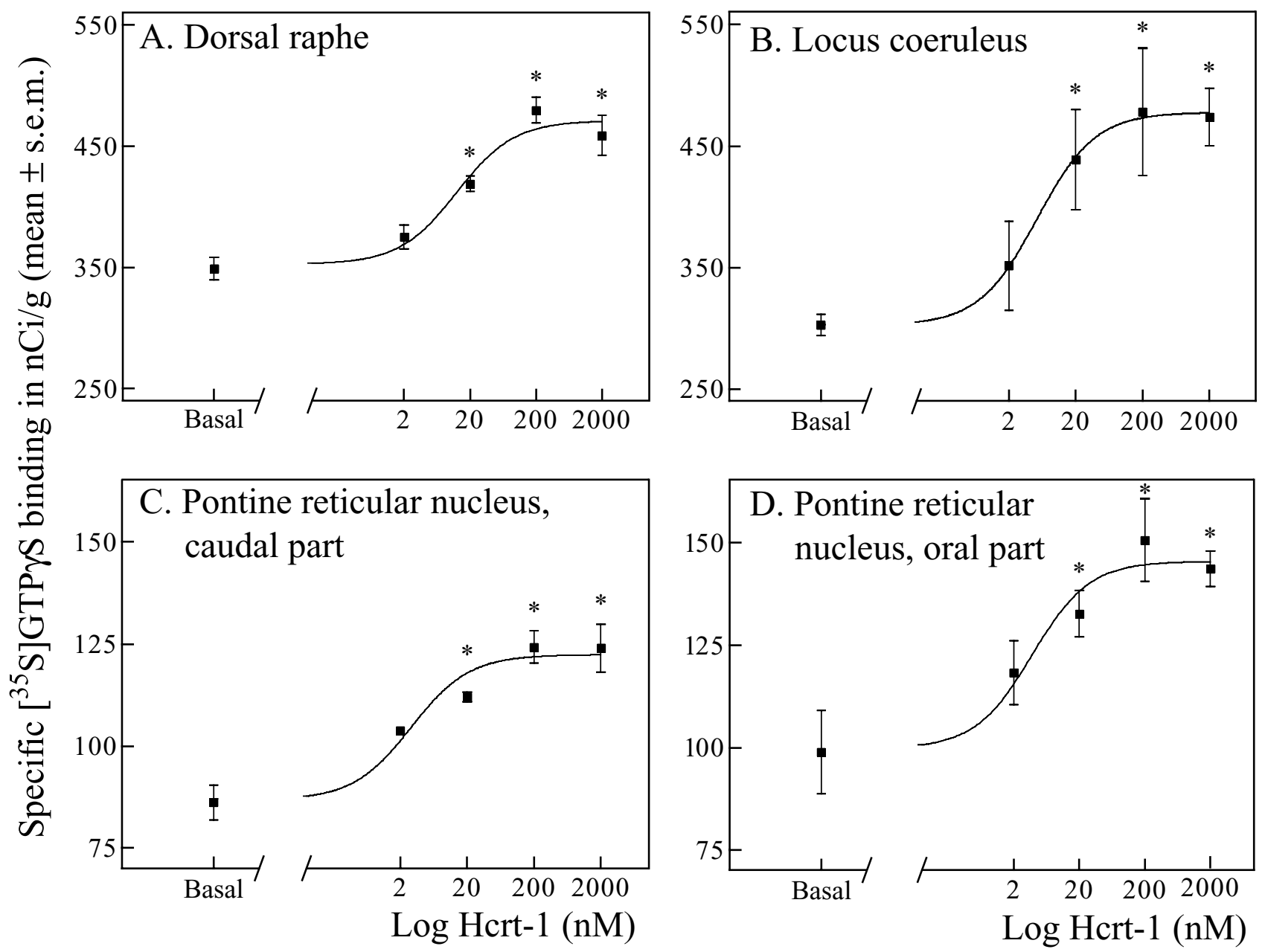

FIG. 2. Concentration-dependent G protein activation by hert-1 in (A) DR, (B) LC, (C) PnC and (D) PnO. Results were obtained from the following number ( $n$ ) of individual measurements: DR, $n=139 ; \mathrm{LC}, n=103$; PnC, $n=299$; and PnO, $n=203$. Specific $\left[{ }^{35} \mathrm{~S}\right] \mathrm{GTP} \gamma \mathrm{S}$ binding following in vitro treatment with 20 , 200, and $2000 \mathrm{nM}$ hcrt-1 was significantly increased $\left({ }^{*} P<0.05\right)$ over basal G protein binding levels. A sigmoid concentration-response curve was fitted to the $\left[{ }^{35} \mathrm{~S}\right] \mathrm{GTP} \gamma \mathrm{S}$ binding data for each nucleus. The resulting coefficients of determination $\left(r^{2}\right)$ were 0.83 (DR), 0.56 (LC), 0.79 (PnC) and 0.69 (PnO). Thus, depending on brain region, $56-83 \%$ of the variance in $\left[{ }^{35} \mathrm{~S}\right] \mathrm{GTP} \gamma \mathrm{S}$ binding was accounted for by the concentration of hert-1. The EC $\mathrm{E}_{50}$ values (nM) calculated from these concentrationresponse data were $12.6(\mathrm{DR}), 5.3(\mathrm{LC}), 2.9(\mathrm{PnC})$ and $3.8(\mathrm{PnO})$. This finding indicates that hort-1 was less potent in DR than in the other nuclei studied.

concentration-dependent, reached saturation, and was fitted by a sigmoid curve (Fig. 2). Any biological process downstream from receptor binding which follows the law of mass action will exhibit a sigmoid shape when plotted as a semilogarithmic concentrationresponse curve (Taylor \& Insel, 1990). This study therefore provides the first direct evidence that hort-1-stimulated $\left[{ }^{35} \mathrm{~S}\right] \mathrm{GTP} \gamma \mathrm{S}$ binding in $\mathrm{DR}, \mathrm{LC}, \mathrm{PnO}$ and $\mathrm{PnC}$ is receptor-mediated.

Confirmation of a receptor-mediated response also is obtained by demonstrating pharmacological antagonism of the response (Limbird, 1996). This study used the competitive antagonist SB-334867 (Smart et al., 2001) to demonstrate that hcrt-1-induced G protein activation is receptor-mediated. SB-334867 has been shown to block electrophysiological (Soffin et al., 2002) and behavioural (Rodgers et al., 2001) responses to hert. Treatment of tissue sections with hert-1 plus SB334867 reduced $\left[{ }^{35} \mathrm{~S}\right] \mathrm{GTP} \gamma \mathrm{S}$ binding to basal levels in all four brain stem nuclei (Fig. 3), providing the first autoradiographic demonstration that hcrt-1-stimulated $\mathrm{G}$ protein activation can be pharmacologically antagonized. The present finding of antagonist blocking agrees with data showing that another hert receptor antagonist, NBI 36487 , blocked hcrt-stimulated $\left[{ }^{35} \mathrm{~S}\right] \mathrm{GTP} \gamma \mathrm{S}$ binding in homogenates of rat pons (Shiba et al., 2002). SB-334867 alone had no effect on $\left[{ }^{35}\right.$ S GTP $y$ S binding (Fig. 3), consistent with reports that SB334867 has no agonist activity (Smart et al., 2001).

\section{Hcrt-1 activated G proteins in additional brain stem nuclei}

$\mathrm{G}$ proteins were activated by hcrt-1 in regions medial to the LC, including the PDTg (Fig. 1). Some authors consider the PDTg of rat to be a homologue of the human dorsal tegmental nucleus, which relays autonomic impulses from the hypothalamus to the reticular formation (Huang et al., 1992). Hcrt-positive fibres have been reported in the intermediolateral cell column of the spinal cord in association with preganglionic sympathetic fibres (Date et al., 2000). Activation of PDTg also is consistent with functional studies indicating that hort excites sympathetic neurons (Antunes et al., 2001).

More rostrally in the brain stem, hcrt-1 activated regions near but outside the boundaries of the DR, including the VLPAG (Fig. 1). VLPAG plays a key role in nociceptive processing (Klamt \& Prado, 1990). G proteins in VLPAG of mouse and rat are activated by the cholinergic agonist carbachol (DeMarco et al., 2003), and cholinergic antinociception has been demonstrated in rat (Ishizawa et al., 2000). The present observation that hert-1 activated G proteins in VLPAG of 


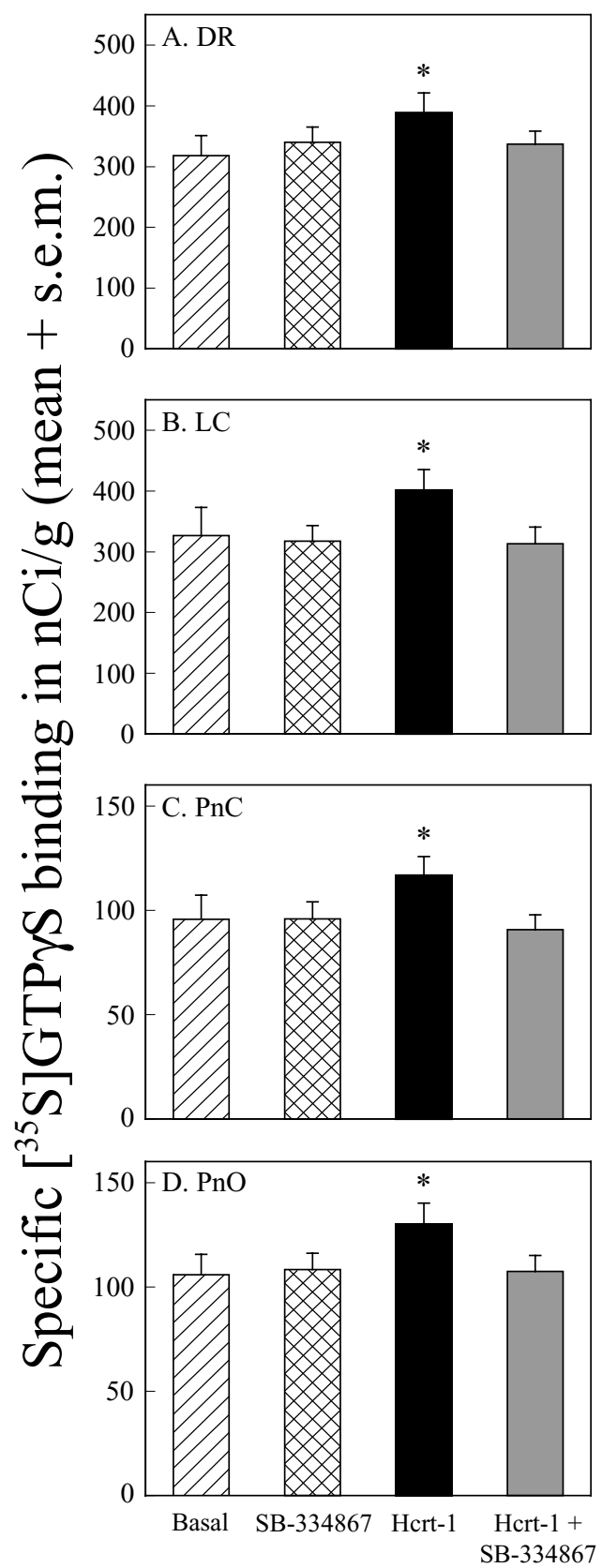

FIG. 3. Hcrt-1-stimulated $\left[{ }^{35} \mathrm{~S}\right] \mathrm{GTP} \gamma \mathrm{S}$ binding was blocked by the hert receptor antagonist SB-334867. Results are based on the following number $(n)$ of individual measurements: DR, $n=295$; LC, $n=158$; PnC, $n=507$; and $\mathrm{PnO}, n=536$. The abscissa indicates the in vitro treatment condition: basal binding (no agonist or antagonist), SB-334867 $(2 \mu \mathrm{M})$, hcrt-1 (200 nM), or hert$1(200 \mathrm{nM})+\mathrm{SB}-334867(2 \mu \mathrm{M}) .{ }^{*} P<0.05$ vs. basal $\left[{ }^{35} \mathrm{~S}\right] \mathrm{GTP} \gamma \mathrm{S}$ binding.

rat is consistent with recent evidence that hert-1 can have antinociceptive effects (Yamamoto et al., 2002).

Finally, Fig. 1 shows that hert-1 activated G proteins in the MnR. Hcrt is a hypothalamic neuropeptide and hort-1 activation of $G$ proteins in $\mathrm{MnR}$ is consistent with neuroanatomical data showing that $\mathrm{MnR}$ is the primary target of lateral hypothalamic fibres projecting to the brain stem (Vertes et al., 1999). Functional studies indicate that $\mathrm{MnR}$ activates hippocampus by mechanisms which include $\mathrm{GABA}_{\mathrm{A}}$ (Kinney et al., 1995) and $\mathrm{GABA}_{\mathrm{B}}$ (Varga et al., 2002)-mediated inhibition of serotonin-containing neurons.
It has been postulated that hcrt contributes to the regulation of arousal states, feeding and sensory-motor processing (Sakurai et al., 1998; Hagan et al., 1999; Yamamoto et al., 2002). Because these diverse functions involve regulation by a plethora of brain stem nuclei, it was anticipated that hcrt-1 would cause widespread activation of $\mathrm{G}$ proteins. The presently reported hcrt-stimulated $\mathrm{G}$ protein activation in multiple brain stem nuclei is consistent with the extensive regional distribution pattern of hort terminals (Peyron et al., 1998), receptor mRNA (Trivedi et al., 1998; Greco \& Shiromani, 2001; Marcus et al., 2001) and receptor protein (Greco \& Shiromani, 2001).

Two controls facilitate functional interpretation of the $\left[{ }^{35} \mathrm{~S}\right] \mathrm{GTP} \gamma \mathrm{S}$ data. First, the cholinergic agonist carbachol was used as a positive control to confirm assay conditions, because carbachol has previously been shown to activate $\mathrm{G}$ proteins in pontine brain stem of rat (Capece et al., 1998) and mouse (DeMarco et al., 2003). In the present study, carbachol increased $\left[{ }^{35} \mathrm{~S}\right] \mathrm{GTP} \gamma \mathrm{S}$ binding over basal levels in DR, LC, $\mathrm{PnC}$ and $\mathrm{PnO}$ by 77, 72, 94 and 74\%, respectively, indicating that the assay was successful. Second, the in vitro autoradiography experiments included a brain region control. Figure 1 clearly shows lack of activation in the fibre pathway comprised of the facial nerve (7n).

\section{Hcrt receptors and G protein subtypes}

Hcrt-r1 and hcrt-r2 both signal through heterotrimeric G proteins (Sakurai et al., 1998). G proteins are classified into subtypes based on the selective interaction of the alpha subunit with a downstream signalling effector molecule (Farfel et al., 1999). The G protein subtypes coupled to hort receptors are still under investigation (reviewed in Kukkonen et al., 2002). Studies using hypothalamic neuronal cell cultures provided evidence that hcrt receptors increase intracellular calcium by coupling to Gq-like G proteins (van den Pol et al., 1998). Hcrt receptors have also been shown to cause direct activation of a calcium influx pathway (Lund et al., 2000). Recent in vitro work using rat (Nanmoku et al., 2000) or human (Karteris et al., 2001; Mazzocchi et al., 2001; Randeva et al., 2001) peripheral tissue suggests that hort receptors interact with Gi-like G proteins.

Agonist-activated $\left[{ }^{35} \mathrm{~S}\right] \mathrm{GTP} \gamma \mathrm{S}$ binding is thought to preferentially label inhibitory G proteins (Kurkinen et al., 1997; Waeber \& Moskowitz, 1997; Laitinen et al., 2001). Accordingly, the present finding that hcrt-1 causes a concentration-dependent antagonist-sensitive increase in $\left[{ }^{35} \mathrm{~S}\right] \mathrm{GTP} \gamma \mathrm{S}$ binding may indicate that some hert receptors in rat brain stem couple to Gi-like G proteins. Several lines of evidence support this possibility. First, hert-induced stimulation of $\left[{ }^{35} \mathrm{~S}\right] \mathrm{GTP} \gamma \mathrm{S}$ binding has also been demonstrated using Chinese hamster ovary cells expressing human hcrt-r2 and using homogenates of rat pons and midbrain (Shiba et al., 2002). Second, recent electrophysiological studies in human embryonic kidney (HEK) cell lines transfected with hcrt-r1 and hcrt-r2 revealed that pertussis toxin (PTX) blocked the hcrt-1-induced conductance increase (Hoang et al., 2003). Because PTX blocks inhibitory $G$ proteins, this finding suggests that hort-r1 and hcrt-r2 can couple to multiple G protein subtypes, including Gi-like G proteins (Hoang et al., 2003). Third, in vitro studies in rat sympathetic preganglionic neurons showed that PTX pretreatment abolished hcrt-1-induced depolarization (van den Top et al., 2003). Fourth, preliminary autoradiographic data indicate that hcrt-1-stimulated $\left[{ }^{35} \mathrm{~S}\right] \mathrm{GTP} \gamma \mathrm{S}$ binding in rat PnO is blocked by PTX (Bernard et al., 2003b). Fifth, in addition to its excitatory properties, hort-1 has been shown to simultaneously produce synaptic excitation and inhibition in the same set of neurons (Davis et al., 2003). These complexities illustrate that signalling pathways activated by hort-1 may differ in LC, DR and pontine reticular formation, despite involvement of the same G protein subtype. An alternate hypothesis is that hort-induced increases in $\left[{ }^{35} \mathrm{~S}\right] \mathrm{GTP} \gamma \mathrm{S}$ binding are caused by indirect activation 
A.

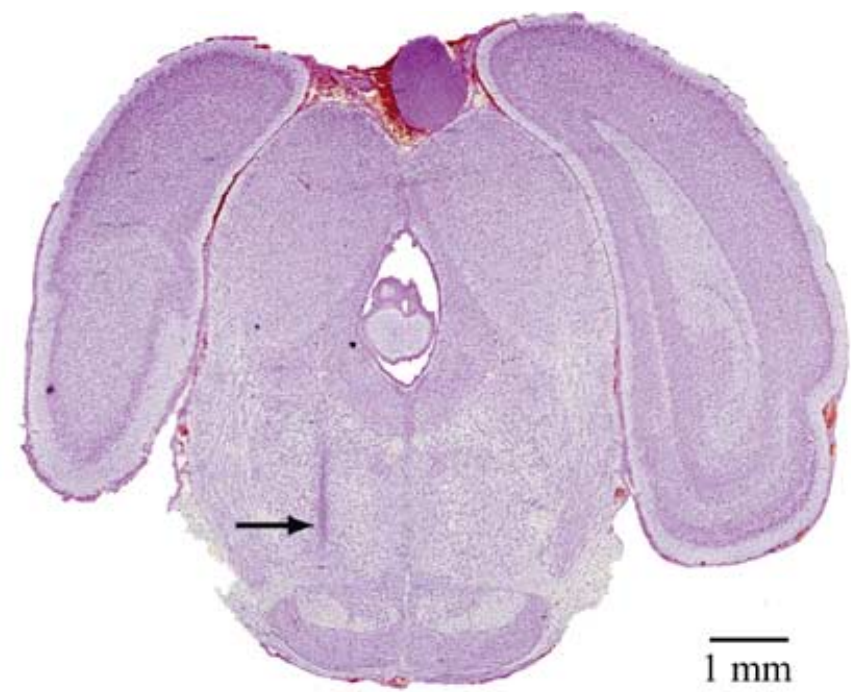

B.

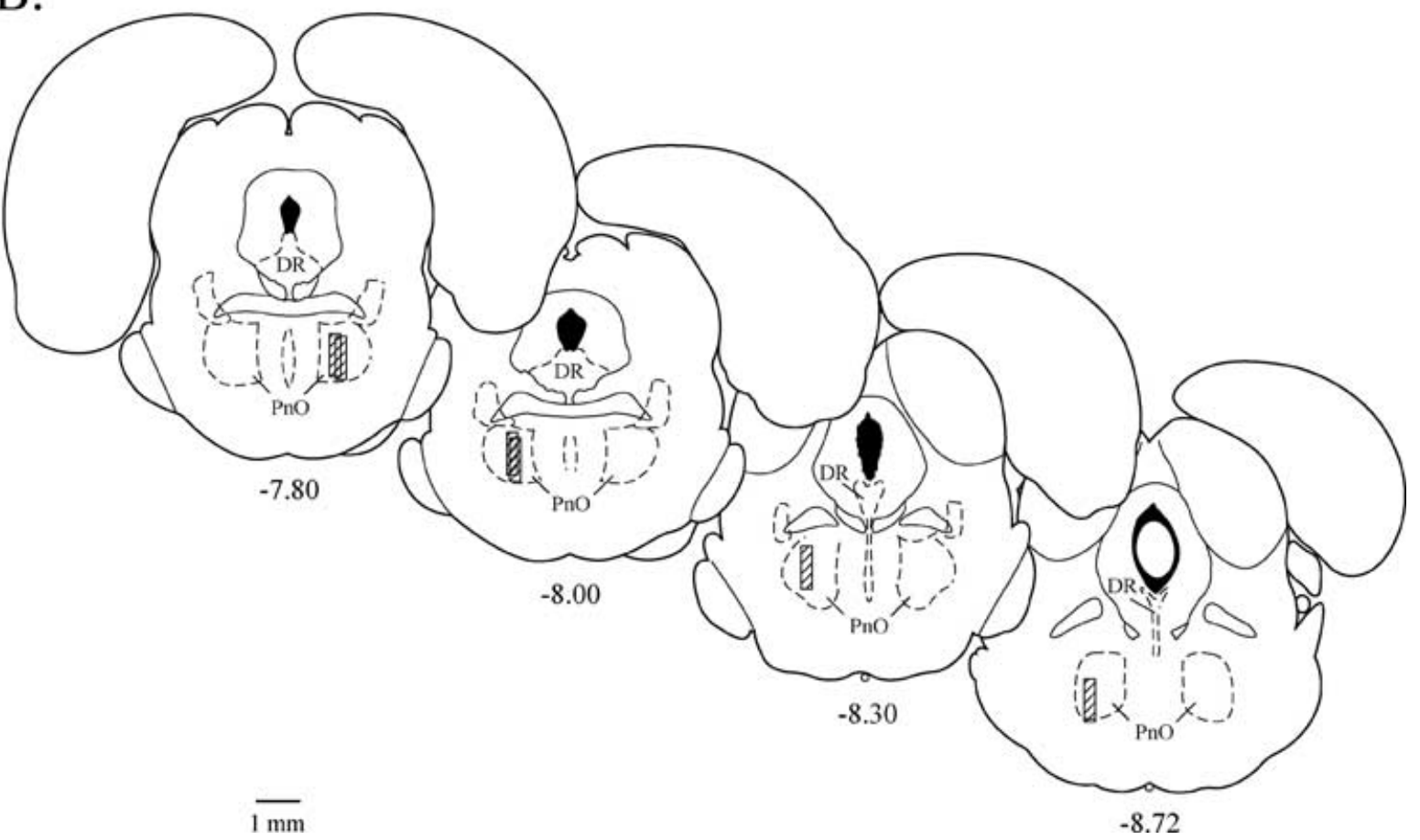

FIG. 4. Histological localization of dialysis sites. (A) Digitized image of a Cresyl Violet-stained brain stem section containing a lesion in the PnO made by a microdialysis probe (arrow). This section is located $\approx 7.9 \mathrm{~mm}$ posterior to bregma. Sections similar to this one were used for histological localization of microdialysis probes in all six animals. (B) Coronal rat brain atlas plates (Paxinos \& Watson, 1998) from 7.80 to $8.72 \mathrm{~mm}$ posterior to bregma show the outlines and location of selected brain stem nuclei, including PnO. Hatched cylinders are drawn to scale and indicate the location of six dialysis sites within the PnO.

of Gi-like G proteins. Indirect activation could result from heterodimerization of hcrt receptors with other G protein-coupled receptors known to activate inhibitory G proteins (Devi, 2001; Angers et al., 2002; Brady \& Limbird, 2002).

\section{ACh release in PnO was modulated by hort-1}

Having demonstrated that activation of hort receptors stimulates $\mathrm{G}$ proteins in arousal-related brain stem nuclei, this study next investigated the effect of hort-1 on ACh release. Direct administration of hcrt into the pontine brain stem increases either wakefulness or REM sleep, depending upon the nucleus injected. Microinjection of hcrt-1 into rat LC (Bourgin et al., 2000) or cat laterodorsal tegmental nucleus (LDT) (Xi et al., 2001) increases wakefulness and suppresses REM sleep. Microinjection of hcrt-1 into a terminal field of cholinergic LDT neurons, the pontine reticular formation, enhances REM sleep in cat (Xi et al., 2002). Hert neurons project to LDT (Peyron et al., 1998; Chemelli et al., 1999), and hcrt excites cholinergic LDT neurons (Burlet et al., 2002). Stimulating LDT and pedunculopontine tegmental nucleus (PPT) neurons causes cortical activation (Steriade, 1993) and increases ACh release in the pontine reticular formation (Lydic \& Baghdoyan, 1993). The cortical activation of wakefulness and REM sleep (Moruzzi, 1972; Steriade, 1993) may be facilitated by excitatory hcrt input to these cholinergic brain stem neurons (Kilduff \& Peyron, 2000).

Cortical ACh release reaches its greatest levels during wakefulness and REM sleep (Jasper \& Tessier, 1971; Marrosu et al., 1995). In the 
A.
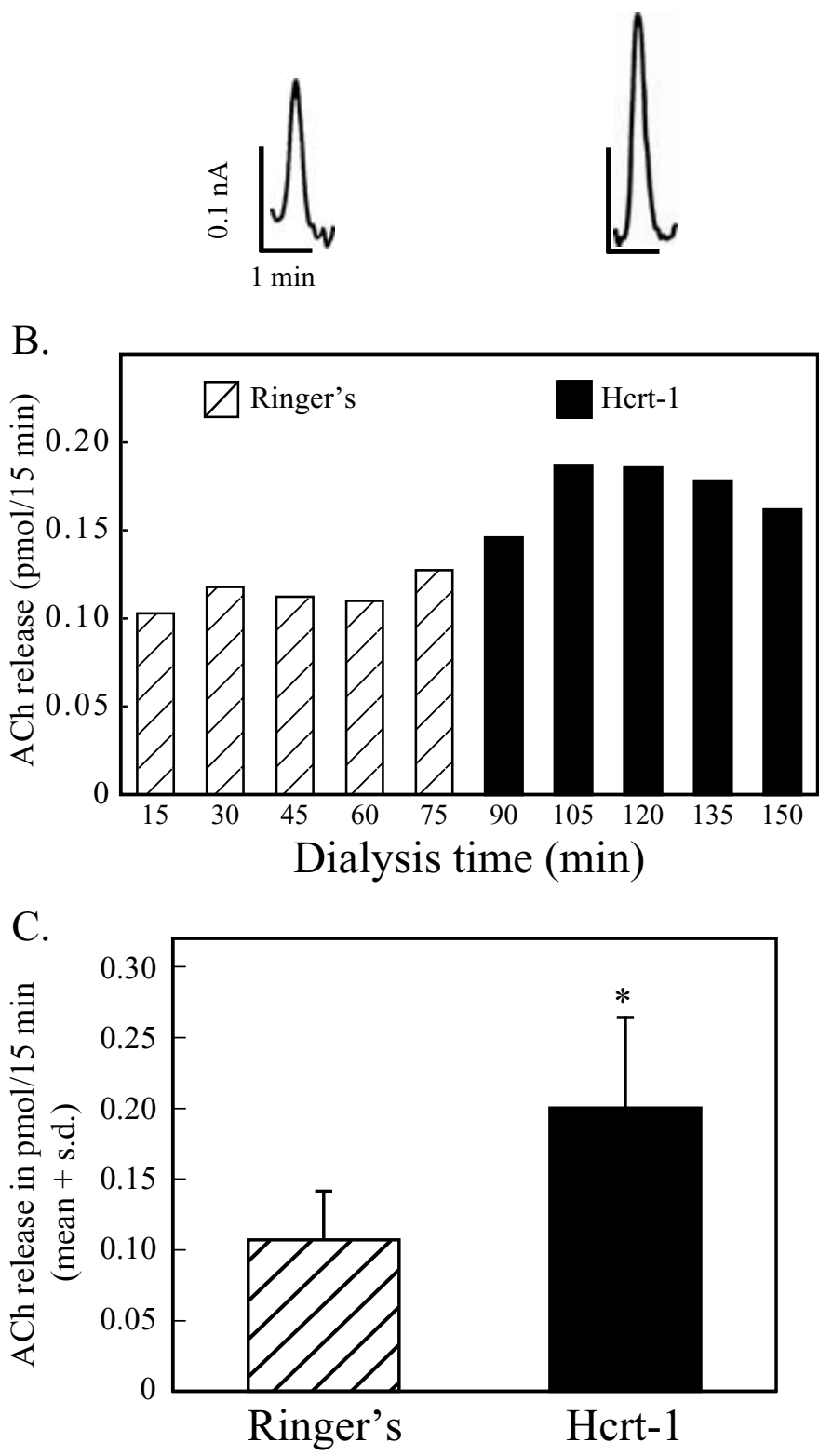

FIG. 5. Dialysis delivery of hert-1 into the PnO increased ACh release. (A) Two typical chromatograms from $\mathrm{PnO}$ dialysis samples obtained during administration of Ringer's $(0.11 \mathrm{pmol} \mathrm{ACh})$ or Ringer's containing hert-1 $(0.19 \mathrm{pmol}$ $\mathrm{ACh}$ ). (B) Time course of ACh release from one representative microdialysis experiment. Hatched bars indicate ACh content in 30- $\mathrm{L}$ samples collected during Ringer's (control) dialysis. Solid bars represent ACh release during dialysis with hort-1. (C) Data were averaged across time for control (Ringer's) samples and for hcrt-1 samples for each experiment, and then across experiments $(n=6)$ to show that hert- 1 caused a significant $\left({ }^{*} P<0.002\right)$ increase in $\mathrm{ACh}$ release.

dorsal tegmental field rostral to LC (Kodama et al., 1990) and in the medial pontine reticular formation (Leonard \& Lydic, 1997), ACh release is significantly greater during REM sleep than during wakefulness. ACh release in the medial pontine reticular formation also changes during the transition from halothane anaesthesia to postanaesthesia wakefulness (Keifer et al., 1996). ACh levels are low during anaesthesia and increase significantly during postanaesthesia wakefulness (Keifer et al., 1996). Taken together, the findings that (i) pontine reticular formation ACh release is increased during states characterized by cortical arousal (Keifer et al., 1996; Leonard \& Lydic, 1997), (ii) hert promotes arousal (Kilduff \& Peyron, 2000) and (iii) hort activates $G$ proteins in the pontine reticular formation (present data) suggested the present hypothesis that hort-1 increases ACh release in the pontine reticular formation.

Dialysis administration of hert-1 to the PnO caused a significant increase in ACh release within the PnO (Figs 4 and 5). This is the first demonstration that hort-1 modulates the release of endogenous ACh in vivo. The results are compatible with the interpretation that one mechanism by which hcrt promotes arousal is by enhancing cholinergic transmission (Kilduff \& Peyron, 2000). The present study did not include any dependent measures of arousal. Future experiments are needed to determine whether hort-induced ACh release in the pontine reticular formation is accompanied by cortical and/or behavioural activation. The present finding of increased ACh release caused by hcrt-1 is consistent with in vitro data showing that hort-1 increased $\left[{ }^{3} \mathrm{H}\right] \mathrm{ACh}$ outflow from enteric cholinergic nerve terminals in ileal strips (Matsuo et al., 2002).

\section{Limitations, methodological considerations and conclusions}

The effects of hcrt-1 on ACh release in PnC were not examined in the present study. $\mathrm{PnC}$ and $\mathrm{PnO}$ comprise the rat pontine reticular formation. The PnO was selected for dialysis because functional mapping studies of rat $\mathrm{PnO}$ and $\mathrm{PnC}$ have shown that the cholinergically evoked REM sleep-like state can be triggered with the shortest latency and greatest duration only from the caudal part of the PnO (Bourgin et al., 1995). This functional site-specificity stands in contrast to the finding that M2 muscarinic receptors are expressed throughout the pontine reticular formation with no difference in M2 receptor density between $\mathrm{PnO}$ and PnC (Baghdoyan, 1997). Previous $\left[{ }^{35} \mathrm{~S}\right] \mathrm{GTP} \gamma \mathrm{S}$ studies also showed no difference in the magnitude of carbachol-stimulated G protein activation between PnO and PnC (Capece et al., 1998).

The present ACh release data were obtained using isofluraneanaesthetized rat. Because ACh release in the medial (Leonard \& Lydic, 1997) and dorsal tegmental (Kodama et al., 1990) portions of the pontine reticular formation changes significantly across the sleepwake cycle, it was necessary to hold arousal state constant with general anaesthesia in order to distinguish between the effects of hort-1 and the effects of arousal state on ACh release. This approach has been used successfully to distinguish between drug- and state-induced changes in ACh release in cat pontine reticular formation (Baghdoyan et al., 1998) and basal forebrain (Vazquez \& Baghdoyan, 2003), rat cortex (Materi et al., 2000) and mouse cortex (Douglas et al., 2001).

The relatively high concentration of hcrt-1 used for the present microdialysis experiments $(100 \mu \mathrm{M})$ was selected based on in vitro data demonstrating that $<0.1 \%$ of a peptide similar in molecular weight to hcrt is delivered through dialysis membranes (Kendrick, 1991). Thus, the estimated concentration of hcrt-1 delivered to the PnO was $\approx 100 \mathrm{nM}$. Hcrt-1-induced G protein activation in PnO occurred at concentrations ranging from 20 to $2000 \mathrm{nM}$ (Fig. 2D). Future studies can determine whether the hcrt-1-induced increase in ACh release is concentration-dependent.

Limitations of the microdialysis technique preclude the ability to specify the mechanisms by which hort-1 significantly increased ACh release in PnO. Existing data regarding synaptic relationships and neurochemical identity of cells in the dorsolateral pons do, however, permit mechanistic speculation. Hcrt neurons are known to project to the pontine reticular formation (Peyron et al., 1998; Chemelli et al., 1999), and the pontine reticular formation has been shown to contain hert receptors (Greco \& Shiromani, 2001; Hervieu et al., 2001). It is also known that rat $\mathrm{PnO}$ contains muscarinic cholinergic receptors 
(Baghdoyan, 1997) and that $\mathrm{PnO}$ neurons are not cholinergic (Jones, 1990). The pontine reticular formation receives cholinergic input from the LDT/PPT (Mitani et al., 1988; Shiromani et al., 1988; Woolf \& Butcher, 1989; Jones, 1990; Semba, 1993), and LDT/PPT neurons release ACh in the pontine reticular formation (Lydic \& Baghdoyan, 1993). Thus, although the synaptic details remain unknown, it is clear that the hcrt-1-stimulated increase in ACh release must involve an effect on LDT/PPT cell bodies, LDT/PPT terminals in the PnO, or both.

How might hort-1 delivered to the PnO alter LDT/PPT terminals and/or cell bodies? Two possible mechanisms are considered here. First, hort-1 may facilitate ACh release by acting directly at hort receptors located presynaptically on cholinergic LDT/PPT terminals within PnO. Second, hcrt-1 depolarizes and increases the discharge rate of pontine reticular formation neurons in vivo (Xi et al., 2002). Pontine reticular formation neurons project to the LDT/PPT nuclei (Semba \& Fibiger, 1992) and are thought to be glutamatergic (Kaneko et al., 1989; Stevens et al., 1992). Glutamate has been shown to excite cholinergic LDT/PPT neurons (Sanchez \& Leonard, 1994). Thus, hcrt delivered by dialysis to the PnO may depolarize PnO neurons which in turn would depolarize LDT/PPT neurons, causing an increase in ACh release from LDT/PPT terminals in the PnO. The ability of PnO to alter LDT/PPT is supported by the finding that unilateral microinjection of carbachol into the pontine reticular formation causes increased ACh release in the contralateral pontine reticular formation (Lydic et al., 1991). The foregoing possible mechanisms are not mutually exclusive and hcrt-1 may modulate ACh release in PnO by a combination of these synaptic relationships. Although speculative, these possibilities are based on existing data and point the way for future experiments aiming to specify synaptic mechanisms by which hort-1 modulates ACh release.

The present finding that hort- 1 increases ACh release in the $\mathrm{PnO}$ is novel and directly relevant to functional studies showing that hcrt-1 administration to PnO triggers a REM-sleep-like state (Xi et al., 2002). Whether hcrt-1 increases ACh release by activating an inhibitory G protein-coupled signal transduction pathway remains to be identified. The present results encourage future studies aiming to determine the synaptic location of hcrt receptors within the PnO.

\section{Acknowledgements}

This work was supported by NIH grants MH45361, HL57120, HL40881 and HL65272, and by the Department of Anaesthesiology. We thank GlaxoSmithKline for supplying SB-334867. G.N. Bowman, C.A. Lapham and M.A. Norat provided expert assistance.

\section{Abbreviations}

$\left[{ }^{35} \mathrm{~S}\right] \mathrm{GTP} \gamma \mathrm{S}, \quad\left[{ }^{35} \mathrm{~S}\right]$ guanylyl-5'-O-( $\boldsymbol{\gamma}$-thio)triphosphate; ACh, acetylcholine; $\mathrm{DR}$, dorsal raphe nucleus; G protein, guanine nucleotide binding protein; GDP, guanosine $5^{\prime}$-diphosphate; GTP $\gamma \mathrm{S}$, guanosine $5^{\prime}$-O- $(\gamma$-thio)triphosphate; hcrt, hypocretin; hcrt-r, hypocretin receptor; LC, locus coeruleus; LDT, laterodorsal tegmental nucleus; MnR, median raphe nucleus; PDTg, posterodorsal tegmental nucleus; $\mathrm{PnC}$, pontine reticular formation, caudal part; $\mathrm{PnO}$, pontine reticular formation, oral part; PPT, pedunculopontine tegmental nucleus; PTX, pertussis toxin; REM, rapid eye movement; VLPAG, ventrolateral periaqueductal grey.

\section{References}

Angers, S., Salahpour, A. \& Bouvier, M. (2002) Dimerization: an emerging concept for $\mathrm{G}$ protein-coupled receptor ontogeny and function. Annu. Rev. Pharmacol. Toxicol., 42, 409-435.

Antunes, V.R., Brailoiu, G.C., Kwok, E.H., Scruggs, P. \& Dun, N.J. (2001) Orexins/hypocretins excite rat sympathetic preganglionic neurons in vivo and in vitro. Am. J. Physiol. Regul. Integr. Comp. Physiol., 281, R1801-R1807.
Baghdoyan, H.A. (1997) Location and quantification of muscarinic receptor subtypes in rat pons: implications for REM sleep generation. Am. J. Physiol., 273, R896-R904.

Baghdoyan, H.A., Lydic, R. \& Fleegal, M.A. (1998) M2 muscarinic autoreceptors modulate acetylcholine release in the medial pontine reticular formation. J. Pharmacol. Exp. Ther., 286, 1446-1452.

Bernard, R., Lydic, R. \& Baghdoyan, H.A. (2002a) Hypocretin-1 activates G proteins in arousal-related brainstem nuclei of rat. Neuroreport, 13, 447-450.

Bernard, R., Lydic, R. \& Baghdoyan, H.A. (2002b) The hypocretin receptor antagonist SB-334867 blocks hypocretin-1-induced G protein activation in sleep-related nuclei of rat brain stem. Soc. Neurosci. Abstr, 28, 870.4.

Bernard, R., Lydic, R. \& Baghdoyan, H.A. (2003a) Hypocretin-1 increases acetylcholine $(\mathrm{ACh})$ release in rat pontine reticular nucleus, oral part $(\mathrm{PnO})$. FASEB J., 17, 390.6.

Bernard, R., Lydic, R. \& Baghdoyan, H.A. (2003b) Pertussis toxin (PTX) blocks hypocretin-1-stimulated $\mathrm{G}$ protein activation in rat pontine reticular nucleus, oral part (PnO). Soc. Neurosci. Abstr., 29, in press.

Bourgin, P., Escourrou, P., Gaultier, C. \& Adrien, J. (1995) Induction of rapid eye movement sleep by carbachol infusion into the pontine reticular formation in the rat. Neuroreport, 6, 532-536.

Bourgin, P., Huitron-Resendiz, S., Spier, A.D., Fabre, V., Morte, B., Criado, J.R., Sutcliffe, J.G., Henriksen, S.J. \& de Lecea, L. (2000) Hypocretin-1 modulates rapid eye movement sleep through activation of locus coeruleus neurons. J. Neurosci., 20, 7760-7765.

Brady, A.E. \& Limbird, L.E. (2002) G protein-coupled receptor interacting proteins: Emerging roles in localization and signal transduction. Cell. Signal., 14, 297-309.

Brown, R.E., Sergeeva, O., Eriksson, K.S. \& Haas, H.L. (2001) Orexin A excites serotonergic neurons in the dorsal raphe nucleus of the rat. Neuropharmacology, 40, 457-459.

Burlet, S., Tyler, C.J. \& Leonard, C.S. (2002) Direct and indirect excitation of laterodorsal tegmental neurons by hypocretin/orexin peptides: implications for wakefulness and narcolepsy. J. Neurosci., 22, 2862-2872.

Capece, M.L., Baghdoyan, H.A. \& Lydic, R. (1998) Carbachol stimulates $\left[{ }^{35}\right.$ S]guanylyl $5^{\prime}$-( $\gamma$-thio) triphosphate binding in REM sleep-related brain stem nuclei of rat. J. Neurosci., 18, 3779-3785.

Chemelli, R.M., Willie, J.T., Sinton, C.M., Elmquist, J.K., Scammell, T., Lee, C., Richardson, J.A., Williams, S.C., Xiong, Y., Kisanuki, Y., Fitch, T.E., Nakazato, M., Hammer, R.E., Saper, C.B. \& Yanagisawa, M. (1999) Narcolepsy in orexin knockout mice: molecular genetics of sleep regulation. Cell, 98, 437-451.

Date, Y., Mondal, M.S., Matsukura, S. \& Nakazato, M. (2000) Distribution of orexin-A and orexin-B (hypocretins) in the rat spinal cord. Neurosci. Lett., 288, 87-90.

Davis, S.F., Williams, K.W., Xu, W., Glatzer, N.R. \& Smith, B.N. (2003) Selective enhancement of synaptic inhibition by hypocretin (orexin) in rat vagal motor neurons: implications for autonomic regulation. J. Neurosci., 23, 3844-3854.

DeMarco, G.J., Baghdoyan, H.A. \& Lydic, R. (2003) Differential cholinergic activation of $\mathrm{G}$ proteins in rat and mouse brainstem: relevance for sleep and nociception. J. Comp. Neurol., 457, 175-184.

Devi, L.A. (2001) Heterodimerization of G-protein-coupled receptors: pharmacology, signaling and trafficking. Trends Pharmacol. Sci., 22, 532-537.

Douglas, C.L., Baghdoyan, H.A. \& Lydic, R. (2001) M2 muscarinic autoreceptors modulate acetylcholine release in prefrontal cortex of C57BL/6J mouse. J. Pharmacol. Exp. Ther, 229, 960-966.

Duxon, M.S., Stretton, J., Starr, K., Jones, D.N.C., Holland, V., Riley, G., Jerman, J.C., Brough, S., Smart, D., Johns, A., Chan, W., Porter, R.A. \& Upton, N. (2001) Evidence that orexin-A-evoked grooming in the rat is mediated by orexin-1 $\left(\mathrm{OX}_{1}\right)$ receptors, with downstream $5-\mathrm{HT}_{2 \mathrm{C}}$ receptor involvement. Psychopharmacology, 153, 203-209.

España, R.A., Baldo, B.A., Kelley, A.E. \& Berridge, C.W. (2001) Wakepromoting and sleep-suppressing actions of hypocretin (orexin): basal forebrain sites of action. Neuroscience, 106, 699-715.

Farfel, Z., Bourne, H.R. \& Iiri, T. (1999) The expanding spectrum of G protein diseases. New Engl. J. Med., 340, 1012-1020.

Gerashchenko, D., Kohls, M.D., Greco, M., Waleh, N.S., Salin-Pascual, R., Kilduff, T.S., Lappi, D.A. \& Shiromani, P.J. (2001) Hypocretin-2-saporin lesions of the lateral hypothalamus produce narcoleptic-like sleep behavior in the rat. J. Neurosci., 21, 7273-7283.

Greco, M.A. \& Shiromani, P.J. (2001) Hypocretin receptor protein and mRNA expression in the dorsolateral pons of rats. Brain Res. Mol. Brain Res., 88, $176-182$.

Hagan, J.J., Leslie, R.A., Patel, S., Evans, M.L., Wattam, T.A., Holmes, S., Benham, C.D., Taylor, S.G., Routledge, C., Hemmati, P., Munton, R.P., 
Ashmeade, T.E., Shah, A.S., Hatcher, J.P., Hatcher, P.D., Jones, D.N., Smith, M.I., Piper, D.C., Hunter, A.J., Porter, R.A. \& Upton, N. (1999) Orexin A activates locus coeruleus cell firing and increases arousal in the rat. Proc. Natl Acad. Sci. USA, 96, 10911-10916.

Hara, J., Beuckmann, C.T., Nambu, T., Willie, J.T., Chemelli, R.M., Sinton, C.M., Sugiyama, F., Yagami, K., Goto, K., Yanagisawa, M. \& Sakurai, T. (2001) Genetic ablation of orexin neurons in mice results in narcolepsy, hypophasia, and obesity. Neuron, 30, 345-354.

Hervieu, G.J., Cluderay, J.E., Harrison, D.C., Roberts, J.C. \& Leslie, R.A. (2001) Gene expression and protein distribution of the orexin-1 receptor in the rat brain and spinal cord. Neuroscience, 103, 777-797.

Hoang, Q.V., Bajic, D., Yanagisawa, M., Nakajima, S. \& Nakajima, Y. (2003) Effects of orexin (hypocretin) on GIRK channels. J. Neurophysiol., 90, 695-702.

Horvath, T.L., Peyron, C., Diano, S., Ivanov, A., Aston-Jones, G., Kilduff, T.S. \& van Den Pol, A.N. (1999) Hypocretin (orexin) activation and synaptic innervation of the locus coeruleus noradrenergic system. J. Comp. Neurol., 415, 145-159.

Huang, X.-F., Törk, I., Halliday, G.M. \& Paxinos, G. (1992) The dorsal, posterodorsal, and ventral tegmental nuclei: a cyto- and chemoarchitectonic study in the human. J. Comp. Neurol., 318, 117-137.

Ishizawa, Y., Ma, H.-C., Dohi, S. \& Shimonaka, H. (2000) Effects of cholinomimetic injection into the brain stem reticular formation on halothane anesthesia and antinociception in rats. J. Pharmacol. Exp. Ther., 293, $845-851$.

Jasper, H.H. \& Tessier, J. (1971) Acetylcholine liberation from cerebral cortex during paradoxical (REM) sleep. Science, 172, 601-602.

Jones, B.E. (1990) Immunohistochemical study of choline acetyltransferaseimmunoreactive processes and cells innervating the pontomedullary reticular formation in the rat. J. Comp. Neurol., 295, 485-514.

Kaneko, T., Itoh, K., Shigemoto, R. \& Mizuno, N. (1989) Glutamine-like immunoreactivity in the lower brainstem and the cerebellum of the adult rat. Neuroscience, 32, 79-98.

Karteris, E., Randeva, H.S., Grammatopoulos, D.K., Jaffe, R.B. \& Hillhouse, E.W. (2001) Expression and coupling characteristics of the CRH and orexin type 2 receptors in human fetal adrenals. J. Clin. Endocrinol. Metab., 86, 4512-4519.

Keifer, J.C., Baghdoyan, H.A. \& Lydic, R. (1996) Pontine cholinergic mechanisms modulate the cortical EEG spindles of halothane anesthesia. Anesthesiology, 84, 945-954.

Kendrick, K.M. (1991) In Vitro Recovery Measurements of Peptides. Peptide Measurement Product Catalog. CMA/Microdialysis, Stockholm, Sweden.

Kilduff, T.S. \& Peyron, C. (2000) The hypocretin/orexin ligand-receptor system: implications for sleep and sleep disorders. Trends Neurosci., 23, 359-365.

Kinney, G.G., Kocsis, B. \& Vertes, R.P. (1995) Injections of muscimol into the median raphe nucleus produce hippocampal theta rhythm in the urethane anesthetized rat. Psychopharmacology, 120, 244-248.

Klamt, J.G. \& Prado, W.A. (1990) Antinociception and behavioral changes induced by carbachol microinjected into identified sites of the rat brain. Brain Res., 549, 9-18.

Kodama, T., Takahashi, Y. \& Honda, Y. (1990) Enhancement of acetylcholine release during paradoxical sleep in the dorsal tegmental field of the cat brain stem. Neurosci. Lett., 114, 277-282.

Kukkonen, J.P., Holmqvist, T., Ammoun, S. \& Åkerman, K.E. (2002) Functions of the orexinergic/hypocretinergic system. Am. J. Physiol. Cell. Physiol., 283, C1567-C1591.

Kurkinen, K.M.A., Koistinaho, J. \& Laitinen, J.T. (1997) $\left[\gamma^{-}{ }^{35}\right.$ S $]$ GTP autoradiography allows region-specific detection of muscarinic receptor-dependent G-protein activation in chick optic tectum. Brain Res., 769, 21-28.

Laitinen, J.T., Asko, U., Raidaru, G. \& Miettinen, R. (2001) $\left[{ }^{35}\right.$ S $]$ GTP $\gamma S$ autoradiography reveals a wide distribution of $\mathrm{G}_{\mathrm{i} / \mathrm{o}}$-linked ADP receptors in the nervous system: close similarities with the platelet $P 2 Y_{A D P}$ receptor. J. Neurochem., 77, 505-518

de Lecea, L., Kilduff, T.S., Peyron, C., Gao, X., Foye, P.E., Danielson, P.E., Fukuhara, C., Battenberg, E.L., Gautvik, V.T., Bartlett, F.S., 2nd, Frankel, W.N., van den Pol, A.N., Bloom, F.E., Gautvik, K.M. \& Sutcliffe, J.G. (1998) The hypocretins: hypothalamus-specific peptides with neuroexcitatory activity. Proc. Natl Acad. Sci. USA, 95, 322-327.

Leonard, T.O. \& Lydic, R. (1997) Pontine nitric oxide modulates acetylcholine release, rapid eye movement sleep generation, and respiratory rate. J. Neurosci., 17, 774-785.

Limbird, L.E. (1996) Cell Surface Receptors: a Short Course on Theory and Methods, 2nd edn. Martinus-Nijhoff Publishing, Boston.

Lin, L., Faraco, J., Li, R., Kadotani, H., Rogers, W., Lin, X., Qiu, X., de Jong, P.J., Nishino, S. \& Mignot, E. (1999) The sleep disorder canine narcolepsy is caused by a mutation in the hypocretin (orexin) receptor 2 gene. Cell, $\mathbf{9 8}$, 365-376.

Lund, P.-E., Shariatmadari, R., Uustare, A., Detheux, M., Parmentier, M., Kukkonen, J.P. \& Åkerman, K.E.O. (2000) The orexin $\mathrm{OX}_{1}$ receptor activates a novel $\mathrm{Ca}^{2+}$ influx pathway necessary for coupling to phospholipase $\mathrm{C}$. J. Biol. Chem., 275, 30806-30812.

Lydic, R. \& Baghdoyan, H.A. (1993) Pedunculopontine stimulation alters respiration and increases $\mathrm{ACh}$ release in the pontine reticular formation. Am. J. Physiol., 264, R544-R554.

Lydic, R., Baghdoyan, H.A. \& Lorinc, Z. (1991) Microdialysis of cat pons reveals enhanced acetylcholine release during state-dependent respiratory depression. Am. J. Physiol., 261, R766-R770.

Marcus, J.N., Aschkenasi, C.J., Lee, C.E., Chemelli, R.M., Saper, C.B., Yanagisawa, M. \& Elmquist, J.K. (2001) Differential expression of orexin receptors 1 and 2 in the rat brain. J. Comp. Neurol., 435, 6-25.

Marrosu, F., Portas, C., Mascia, M.S., Casu, M.A., Fa, M., Giagheddu, M., Imperato, A. \& Gessa, G.L. (1995) Microdialysis measurement of cortical and hippocampal acetylcholine release during sleep-wake cycle in freely moving cats. Brain Res., 671, 329-332.

Materi, L.M., Rasmusson, D.D. \& Semba, K. (2000) Inhibition of synaptically evoked cortical acetylcholine release by adenosine: an in vivo microdialysis study in the rat. Neuroscience, 97, 219-226.

Matsuo, K., Kaibara, M., Uezono, Y., Hayashi, H., Taniyama, K. \& Nakane, Y. (2002) Involvement of cholinergic neurons in orexin-induced contraction of guinea pig ileum. Eur. J. Pharmacol., 452, 105-109.

Mazzocchi, G., Malendowicz, L.K., Aragona, F., Rebuffat, P., Gottardo, L. \& Nussdorfer, G.G. (2001) Human pheochromocytomas express orexin receptor type 2 gene and display an in vitro secretory response to orexins A and B. J. Clin. Endocrinol. Metab., 86, 4818-4821.

Mitani, A., Ito, K., Hallanger, A.E., Wainer, B.H., Kataoka, K. \& McCarley, R.W. (1988) Cholinergic projections from the laterodorsal and pedunculopontine tegmental nuclei to the pontine gigantocellular tegmental field in the cat. Brain Res., 451, 397-402.

Moruzzi, G. (1972) The sleep-waking cycle. Ergebn. Physiol., 64, 1-165.

Nanmoku, T., Isobe, K., Sakurai, T., Yamanaka, A., Takekoshi, K., Kawakami, Y., Ishii, K., Goto, K. \& Nakai, T. (2000) Orexins suppress catecholamine synthesis and secretion in cultured PC12 cells. Biochem. Biophys. Res. Com., 274, 310-315.

Nishino, S. \& Mignot, E. (1997) Pharmacological aspects of human and canine narcolepsy. Prog. Neurobiol., 52, 27-78.

Nishino, S., Ripley, B., Overeem, S., Lammers, G.J. \& Mignot, E. (2000) Hypocretin (orexin) deficiency in human narcolepsy. Lancet, 355, 39-40.

Nishino, S., Ripley, B., Overeem, S., Nevsimalova, S., Lammers, G.J., Vankova, J., Okun, M., Rogers, W., Brooks, S. \& Mignot, E. (2001) Low cerebrospinal fluid hypocretin (orexin) and altered energy homeostasis in human narcolepsy. Ann. Neurol., 50, 381-388.

Paxinos, G. \& Watson, C. (1998) The Rat Brain in Stereotaxic Coordinates, 4th edn. Academic Press, New York.

Peyron, C., Faraco, J., Rogers, W., Ripley, B., Overeem, S., Charnay, Y., Nevsimalova, S., Aldrich, M., Reynolds, D., Albin, R., Li, R., Hungs, M., Pedrazzoli, M., Padigaru, M., Kucherlapati, M., Fan, J., Maki, R., Lammers, G.J., Bouras, C., Kucherlapati, R., Nishino, S. \& Mignot, E. (2000) A mutation in a case of early onset narcolepsy and a generalized absence of hypocretin peptides in human narcoleptic brains. Nature Med., 6, 991-997.

Peyron, C., Tighe, D.K., van den Pol, A.N., de Lecea, L., Heller, H.C., Sutcliffe, J.G. \& Kilduff, T.S. (1998) Neurons containing hypocretin (orexin) project to multiple neuronal systems. J. Neurosci., 18, 9996-10015.

Piper, D.C., Upton, N., Smith, M.I. \& Hunter, A.J. (2000) The novel brain neuropeptide, orexin-A, modulates the sleep-wake cycle of rats. Eur. J. Neurosci., 12, 726-730.

van den Pol, A.N., Gao, X.B., Obrietan, K., Kilduff, T.S. \& Belousov, A.B. (1998) Presynaptic and postsynaptic actions and modulation of neuroendocrine neurons by a new hypothalamic peptide, hypocretin/orexin. J. Neurosci., 18, 7962-7971.

Randeva, H.S., Karteris, E., Grammatopoulos, D. \& Hillhouse, E.W. (2001) Expression of orexin-A and functional orexin type 2 receptors in the human adult adrenals: implications for adrenal function and energy homeostasis. J. Clin. Endocrinol. Metab., 86, 4808-4813.

Rodgers, R.J., Halford, J.C.G., Nunes de Souza, R.L., Canto de Souza, A.L., Piper, D.C., Arch., J.R.S., Upton, N., Porter, R.A., Johns, A. \& Blundell, J.E. (2001) SB-334867, a selective orexin-1 receptor antagonist, enhances behavioral satiety and blocks the hyperphagic effect of orexin-A in rats. Eur. J. Neurosci., 13, 1444-1452.

Sakurai, T., Amemiya, A., Ishii, M., Matsuzaki, I., Chemelli, R.M., Tanaka, H., Williams, S.C., Richardson, J.A., Kozlowski, G.P., Wilson, S., Arch., J.R., 
Buckingham, R.E., Haynes, A.C., Carr, S.A., Annan, R.S., McNulty, D.E., Liu, W.S., Terrett, J.A., Elshourbagy, N.A., Bergsma, D.J. \& Yanagisawa, M. (1998) Orexins and orexin receptors: a family of hypothalamic neuropeptides and $\mathrm{G}$ protein-coupled receptors that regulate feeding behavior. Cell, 92, 573-585.

Sanchez, R. \& Leonard, C.S. (1994) NMDA receptor-mediated synaptic input to nitric oxide synthase-containing neurons of the guinea pig mesopontine tegmentum in vitro. Neurosci. Lett., 197, 141-144.

Scammell, T.E. (2003) The neurobiology, diagnosis, and treatment of narcolepsy. Ann. Neurol., 53, 154-166.

Semba, K. (1993) Aminergic and cholinergic afferents to REM sleep induction regions of the pontine reticular formation in the rat. J. Comp. Neurol., 330, $543-556$.

Semba, K. \& Fibiger, H.C. (1992) Afferent connections of the laterodorsal and the pedunculopontine tegmental nuclei in rat: a retro- and antero-grade transport and immunohistochemical study. J. Comp. Neurol., 323, 387-410.

Shiba, T., Ozu, M., Yoshida, Y., Mignot, E. \& Nishino, S. (2002) Hypocretin stimulates $\left[{ }^{35} \mathrm{~S}\right] \mathrm{GTP} \gamma \mathrm{S}$ binding in hertr 2-transfected cell lines and in brain homogenate. Biochem. Biophys. Res. Com., 294, 615-620.

Shiromani, P.J., Armstrong, D.M. \& Gillin, J.C. (1988) Cholinergic neurons from the dorsolateral pons project to the medial pons: a WGA-HRP and choline acetyltransferase immunohistochemical study. Neurosci. Lett., 95, $19-23$.

Sim, L.J., Selley, D.E. \& Childers, S.R. (1995) In vitro autoradiography of receptor-activated $\mathrm{G}$ proteins in rat brain by agonist-stimulated guanylyl $5^{\prime}-\left[\gamma-\left[{ }^{35}\right.\right.$ S $]$ thio $]$-triphosphate binding. Proc. Natl Acad. Sci. USA, 92, $7242-7246$.

Smart, D., Sabido-David, C., Brough, S.J., Jewitt, F., Johns, A., Porter, R.A. \& Jerman, J.C. (2001) SB-334867-A: the first selective orexin-1 receptor antagonist. Br. J. Pharmacol., 132, 1179-1182.

Soffin, E.M., Evans, M.L., Gill, C.H., Harries, M.H., Benham, C.D. \& Davies, C.H. (2002) SB-334867-A antagonises orexin mediated excitation in the locus coeruleus. J. Neuropharmacol., 42, 127-133.

Sóvágó, J., Dupuis, D.S. \& Gulyás, B. (2001) An overview on functional receptor autoradiography using $\left[{ }^{35} \mathrm{~S}\right] \mathrm{GTP} \gamma \mathrm{S}$ autoradiography. Brain Res. Rev., 38, 148-164.

Steriade, M. (1993) Cholinergic blockage of network- and intrinsically-generated slow oscillations promotes waking and REM sleep activity patterns in thalamic and cortical neurons. Prog. Brain Res., 98, 345-355.
Stevens, D.R., McCarley, R.W. \& Greene, R.W. (1992) Excitatory amino acidmediated responses and synaptic potentials in medial pontine reticular formation neurons of the rat in vitro. J. Neurosci., 12, 4188-4194.

Taylor, P. \& Insel, P.A. (1990) Molecular basis of pharmacologic selectivity. In Pratt, W.B. \& Taylor, P. (eds), Principles of Drug Action: the Basis of Pharmacology. Churchill Livingstone, New York, pp. 1-102.

Thannickal, T.C., Moore, R.Y., Nienhuis, R., Ramanathan, L., Gulyani, S., Aldrich, M., Comford, M. \& Siegel, J.M. (2000) Reduced number of hypocretin neurons in human narcolepsy. Neuron, 27, 469-474.

van den Top, M., Nolan, M.F., Lee, K., Richardson, P.J., Buijs, R.M., Davies, C. $\&$ Spanswick, D. (2003) Orexins induce increased excitability and synchronisation of rat sympathetic preganglionic neurones. J. Physiol. (Lond.), 549, 809-821.

Trivedi, P., YuH., MacNeil, D.J., Van der Ploeg, L.H.T. \& Guan, X.-M. (1998) Distribution of orexin receptor mRNA in the rat brain. FEBS Lett., 438, 71-75.

Varga, V., Sik, A., Freund, T.F. \& Kocsis, B. (2002) $\mathrm{GABA}_{\mathrm{B}}$ receptors in the median raphe nucleus: Distribution and role in the serotonergic control of hippocampal activity. Neuroscience, 109, 119-132.

Vazquez, J. \& Baghdoyan, H.A. (2003) Muscarinic and $\mathrm{GABA}_{\mathrm{A}}$ receptors modulate acetylcholine release in feline basal forebrain. Eur. J. Neurosci., 17, 249-259.

Vertes, R.P., Fortin, W.J. \& Crane, A.M. (1999) Projections of the median raphe nucleus in the rat. J. Comp. Neurol., 407, 555-582.

Waeber, C. \& Moskowitz, M.A. (1997) 5-hydroxytryptamine ${ }_{1 \mathrm{~A}}$ and 5-hydroxytryptamine $_{1 \mathrm{~B}}$ receptors stimulated $\left[{ }^{35} \mathrm{~S}\right]$ guanosine-5'-O-(3-thio) triphosphate binding to rodent brain sections as visualized by in vitro autoradiography. Mol. Pharmacol., 52, 623-631.

Woolf, N.J. \& Butcher, L.L. (1989) Cholinergic systems in the rat brain. IV. Descending projections of the pontomesencephalic tegmentum. Brain Res. Bull., 23, 519-540.

Xi, M.-C., Fung, S.J., Yamuy, J., Morales, F.R. \& Chase, M.H. (2002) Induction of active (REM) sleep by microinjection of hypocretin into the nucleus pontis oralis of the cat. J. Neurophysiol., 87, 2880-2888.

Xi, M., Morales, F.R. \& Chase, M.H. (2001) Effects on sleep and wakefulness of the injection of hypocretin-1 (orexin-A) into the laterodorsal tegmental nucleus of the cat. Brain Res., 901, 259-264.

Yamamoto, T., Nozaki-Taguchi, N. \& Chiba, T. (2002) Analgesic effect of intrathecally administered orexin-A in the rat formalin test and in the rat hot plate test. Br. J. Pharmacol., 137, 170-176. 